\title{
Rekomendasi Pemupukan Fosfor pada Budidaya Caisin (Brassica rapa L. cv. caisin) di Tanah Andosol
}

\author{
Phosphorus Fertilizer Recommendation for Caisin (Brassica rapa L. cv. caisin) \\ Cultivated on Andosol Soil \\ Donatila Faranso $^{1}$ dan Anas D. Susila ${ }^{1 *}$
}

Diterima 19 Agustus 2015/Disetujui 09 November 2015

\begin{abstract}
This study was conducted to determine optimum phosphorus fertilizer application in Andosols soil, at the Pasir Sarongge, IPB Experimental Farm, Cianjur from April to May 2014. This research was arranged in split plot design with main plot five soil $P$ status, namely $X\left(1856.3 \mathrm{~kg}^{2} \cdot \mathrm{ha}^{-1} \mathrm{P}_{2} \mathrm{O}_{5}\right)$, $3 / 4 X\left(1392.225 \mathrm{~kg} . \mathrm{ha}^{-1} \mathrm{P}_{2} \mathrm{O}_{5}\right), 1 / 2 \mathrm{X}\left(928.15 \mathrm{~kg} \cdot \mathrm{ha}^{-1} \mathrm{P}_{2} \mathrm{O}_{5}\right), 1 / 4 \mathrm{X}\left(464.076 \mathrm{~kg} \cdot \mathrm{ha}^{-1} \mathrm{P}_{2} \mathrm{O}_{5}\right)$ and $0 \mathrm{X}(0$ $\left.\mathrm{kg} \cdot \mathrm{ha}^{-1} \mathrm{P}_{2} \mathrm{O}_{5}\right)$ and subplot five $\mathrm{P}$ fertilizer rates, namely $\left(1856.3 \mathrm{~kg} \cdot \mathrm{ha}^{-1} \mathrm{P}_{2} \mathrm{O}_{5}\right), 3 / 4 \mathrm{X}(1392.225$

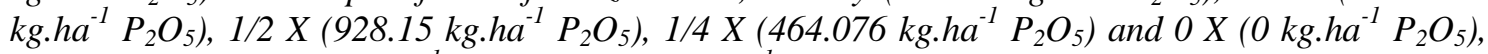
where $X=1856.346 \mathrm{~kg} . \mathrm{ha}^{-1} \mathrm{P}_{2} \mathrm{O}_{5}$ or $5156 \mathrm{~kg} \cdot \mathrm{ha}^{-1} \mathrm{SP}-36$, in which $\mathrm{P}$ was needed to achieve the highest levels of $P$ in Pasir Sarongge Andosol. Rate of $N$ and $K$ were applied at $200 \mathrm{~kg} . \mathrm{ha}^{-1}$ of Urea $(45 \% \mathrm{~N})$ and $100 \mathrm{~kg} \cdot \mathrm{ha}^{-1} \mathrm{KCl}\left(60 \% \mathrm{~K}_{2} \mathrm{O}\right)$ respectively. The results showed that the soil nutrient $P$ was able to enhance the growth and yield of caisin, whereas $P$ fertilization treatment did not give significant effect on caisin growth and yield in the medium P content (Bray extractant) of Pasir Sarongge Andosols. The percentage of plants affected by mace root disease was 11.90\%. It may influence the effectiveness of $P$ fertilization. The $P$ fertilizer rate recommendations in the Pasir Sarongge Andosol could not be determined.
\end{abstract}

Keywords: fertilizer, $P$ soils, vegetables, rate

\begin{abstract}
ABSTRAK
Penelitian ini dilakukan untuk menentukan dosis optimum pemupukan fosfor pada tanah Andosol. Penelitian dilakukan di Kebun Percobaan IPB Pasir Sarongge Cianjur mulai April hingga Mei 2014. Percobaan disusun rancangan Split Plot. Petak utama (main plot) adalah status hara $\mathrm{P}$ tanah yang diinkubasikan dari terdiri atas lima, 3/4 X (1392.225 kg.ha $\left.{ }^{-1} \mathrm{P}_{2} \mathrm{O}_{5}\right), 1 / 2 \mathrm{X}\left(928.15 \mathrm{~kg}^{-1} \mathrm{ha}^{-1}\right.$ $\left.\mathrm{P}_{2} \mathrm{O}_{5}\right), 1 / 4 \mathrm{X}\left(464.076 \mathrm{~kg} \cdot \mathrm{ha}^{-1} \mathrm{P}_{2} \mathrm{O}_{5}\right)$ dan $0 \mathrm{X}\left(0 \mathrm{~kg} \cdot \mathrm{ha}^{-1} \mathrm{P}_{2} \mathrm{O}_{5}\right)$, dimana $\mathrm{X}\left(1856.3 \mathrm{~kg} \cdot \mathrm{ha}^{-1} \mathrm{P}_{2} \mathrm{O}_{5}\right)$, Anak Petak (sub plot) adalah dosis pemupukan $\mathrm{P}$ yang terdiri atas lima taraf, yaitu $\mathrm{X}$ (1856.3 kg.ha ${ }^{-1}$ $\left.\mathrm{P}_{2} \mathrm{O}_{5}\right), 3 / 4 \mathrm{X}\left(1392.225 \mathrm{~kg} \cdot \mathrm{ha}^{-1} \mathrm{P}_{2} \mathrm{O}_{5}\right), 1 / 2 \mathrm{X}\left(928.15 \mathrm{~kg} \cdot \mathrm{ha}^{-1} \mathrm{P}_{2} \mathrm{O}_{5}\right), 1 / 4 \mathrm{X}\left(464.076 \mathrm{~kg} \cdot \mathrm{ha}^{-1} \mathrm{P}_{2} \mathrm{O}_{5}\right)$ dan $0 \mathrm{X}\left(0 \mathrm{~kg} \cdot \mathrm{ha}^{-1} \mathrm{P}_{2} \mathrm{O}_{5}\right)$ dengan $\mathrm{X}=1856.346 \mathrm{~kg} \cdot \mathrm{ha}^{-1} \mathrm{P}_{2} \mathrm{O}_{5}$ atau $5156 \mathrm{~kg} \cdot \mathrm{ha}^{-1} \mathrm{SP}-36$, yaitu $\mathrm{P}$ yang dibutuhkan untuk mencapai kadar P sangat tinggi pada tanah Andosol Pasir Sarongge. Dosis N dan $\mathrm{K}$ yang digunakan adalah $200 \mathrm{~kg} \mathrm{~kg} \cdot \mathrm{ha}^{-1}$ Urea $(45 \% \mathrm{~N})$ dan $100 \mathrm{~kg} \cdot \mathrm{ha}^{-1} \mathrm{KCl}\left(60 \% \mathrm{~K}_{2} \mathrm{O}\right)$. Status hara awal hara $\mathrm{P}$ tanah berpengaruh sangat nyata terhadap pertumbuhan dan hasil tanaman caisin. Namun demikian, perlakuan pemupukan $P$ tidak memberikan pengaruh yang nyata terhadap pertumbuhan dan hasil tanaman caisin pada tingkat kesuburan $\mathrm{P}$ tanah sedang menurut pengekstrak Bray. Serangan penyakit akar gada kemungkinan dapat menjadi penyebab pemupukan tidak berpengaruh pada tanaman. Persentase jumlah tanaman yang terserang penyakit akar gada adalah $11.90 \%$. Dosis rekomendasi pemupukan P untuk tanaman caisin di kebun Percobaan Pasir Sarongge belum dapat ditentukan.
\end{abstract}

Kata kunci: pupuk, P tanah, sayuran, dosis

${ }^{1}$ Departemen Agronomi dan Hortikultura, Fakultas Pertanian, Institut Pertanian Bogor (Bogor Agricultural University), Jl. Meranti Kampus Darmaga, Bogor 16680 Indonesia. Telp.\&Faks. 62-251-8629353. email: anasdsusila10@ gmail.com. (*penulis korespondensi) 


\section{PENDAHULUAN}

Jumlah konsumsi sayuran masyarakat di Indonesia saat ini sebesar $34 \mathrm{~kg}$ per kapita per tahun (BPS, 2013). Berdasarkan data tersebut dapat diketahui bahwa tingkat konsumsi masyarakat Indonesia terhadap sayuran masih rendah jika dibandingkan dengan jumlah konsumsi sayuran masyarakat di negara Tiongkok dan standar yang ditetapkan oleh FAO. Pada tahun 1995 konsumsi sayuran di Tiongkok mencapai $143 \mathrm{~kg}$ per kapita per tahun dan jumlah tersebut telah melebihi standar konsumsi sayuran menurut FAO. Konsumsi sayuran berdasarkan standar yang ditetapkan oleh FAO adalah sebesar $73 \mathrm{~kg}$ per kapita per tahun (FAO, 2006).

Sayur caisin mengalami penurunan jumlah produksi sebesar $8 \%$ selama periode 2011-2012. Produksi caisin pada tahun 2011 sebesar 581,000 ton dan pada tahun 2012 mengalami penurunan menjadi 531,000 ton (Kementan, 2012). Produksi caisin yang rendah disebabkan oleh rendahnya produk-tivitas caisin per hektar dan teknik budidaya yang kurang tepat. Penurunan produksi caisin dan beberapa sayuran lainnya tentu menjadi masalah apabila tidak dilakukan upaya perbaikan. Upaya perbaikan yang dapat dilakukan salah satunya adalah dengan melakukan pemupukan.

Pemupukan adalah kegiatan menambah unsur hara tertentu untuk memenuhi kebutuhan tanaman yang tidak dapat disediakan oleh tanah. Pemupukan dapat meningkatkan hasil panen dan kandungan hara yang ada pada sayuran (Wang et al., 2008). Indeks panen secara signifikan meningkat seiring dengan meningkatnya aplikasi fosfor (Motlagh et al., 2012). Pemupukan yang dilakukan secara tidak tepat berdampak buruk pada lingkungan dan tanaman. Penambahan $\mathrm{P}$ secara terus menerus menyebabkan terjadinya akumulasi P pada permukaan atas tanah (Fei et al., 2011). Kesalahan dalam aplikasi pemupukan dapat berdampak pada hilangnya energi dan biaya yang dikeluarkan semakin tinggi (Savci, 2012).

Petani di Indonesia sebagian besar melakukan pemupukan hanya berdasarkan pengalaman dari kegiatan bertanam sebelumnya atau menggunakan rekomendasi pemupukan yang tertera dikemasan pupuk yang digunakan. Padahal dosis rekomendasi yang ada pada kemasan belum tentu dibuat berdasarkan kategori status hara tanah. Dosis rekomendasi pemupukan untuk setiap wilayah harus memperhatikan tingkat kesuburan tanah dan jumlah unsur hara yang dibutuhkan oleh tanaman. Pembuatan dosis pupuk harus didasarkan pada hasil dan tingkat hara tanah (Toth et al., 2014). Konsep pemupukan $\mathrm{P}$ berdasarkan uji tanah atau rekomendasi spesifik lokasi harus menjadi perhatian utama dan perlu dilakukan secara berulang (Izhar, 2012).

Ketersediaan hara P pada tanah Andosol sangat terbatas. Terbatasnya jumlah hara $\mathrm{P}$ pada tanah Andosol disebabkan oleh adanya retensi. Reaksi retensi dapat terjadi antara $P$ dan $\mathrm{Al}$ atau antara $\mathrm{P}$ dan Fe. Produk yang dihasilkan oleh retensi sukar larut dalam air dan menjadi endapan sehingga sulit tersedia bagi tanaman. Rendahnya $\mathrm{pH}$ tanah akan berakibat pada semakin tinggnya konsentrasi $\mathrm{Al}, \mathrm{Fe}$, dan $\mathrm{Mn}$ yang dapat larut, sehingga semakin besar pula jumlah $\mathrm{P}$ yang diikat dengan cara ini (Tan, 1998). Ketersediaan P pada tanah juga dipengaruhi oleh irigasi (Wang dan Zhang, 2010). Tujuan penelitian ini adalah mendapatkan dosis optimal pemupukan P untuk budidaya tanaman caisin pada tanah Andosol Pasir Sarongge.

\section{BAHAN DAN METODE}

Percobaan dilaksanakan mulai April hingga Mei 2014 di Kebun Percobaan Pasir Sarongge, Desa Ciputri, Kecamatan Pacet, Kabupaten Cianjur, Jawa Barat. Ketinggian lokasi penelitian adalah 1,200 meter di atas permukaan laut (mdpl), kemiringan $3-40 \%$, curah hujan 2,000-3,000 mm per tahun, dan jenis tanah Andosol. Analisis tanah dilakukan di SEAMEO Biotrop Services Laboratory.

Bahan yang digunakan yaitu pupuk. SP-36 $\left(36 \% \mathrm{P}_{2} \mathrm{O}_{5}\right)$, pupuk standar Urea (45\% N) dan $\mathrm{KCl}\left(60 \% \mathrm{~K}_{2} \mathrm{O}\right)$, benih caisin varietas Tosakan, dan media semai. Alat yang digunakan adalah tray, penakar, cangkul, kored, timbangan, meteran, tali, ember, dan alat tulis.

Percobaan ini menggunakan rancangan perlakuan Split Plot yang disusun dengan rancangan kelompok lengkap teracak (RKLT) dan diulang sebanyak empat kali ulangan. Bedeng utama (main plot) adalah Status hara awal hara $\mathrm{P}$ tanah yang diinkubasi dengan lima 
taraf P, yaitu X (1856.3 kg.ha $\left.{ }^{-1} \mathrm{P}_{2} \mathrm{O}_{5}\right), 3 / 4 \mathrm{X}$ (1392.2 kg.ha $\left.{ }^{-1} \mathrm{P}_{2} \mathrm{O}_{5}\right), 1 / 2 \times\left(928.1 \mathrm{~kg} \cdot \mathrm{ha}^{-1}\right.$ $\left.\mathrm{P}_{2} \mathrm{O}_{5}\right), 1 / 4 \mathrm{X}\left(464.1\right.$ kg.ha $\left.{ }^{-1} \mathrm{P}_{2} \mathrm{O}_{5}\right)$, dan $0 \mathrm{X}(0$ kg.ha ${ }^{-1} \mathrm{P}_{2} \mathrm{O}_{5}$ ). Anak bedeng (sub plot) adalah dosis pemupukan $\mathrm{P}$ yang terdiri atas lima taraf, yaitu X (1856.3 kg.ha $\left.{ }^{-1} \mathrm{P}_{2} \mathrm{O}_{5}\right), 3 / 4 \mathrm{X}(1392.2$ kg.ha $\left.{ }^{-1} \mathrm{P}_{2} \mathrm{O}_{5}\right), 1 / 2 \mathrm{X}\left(928.1 \mathrm{~kg} \cdot \mathrm{ha}^{-1} \mathrm{P}_{2} \mathrm{O}_{5}\right), 1 / 4$ $\mathrm{X}\left(464.1 \mathrm{~kg} \cdot \mathrm{ha}^{-1} \mathrm{P}_{2} \mathrm{O}_{5}\right)$, dan 0X $\left(0 \mathrm{~kg} \cdot \mathrm{ha}^{-1}\right.$ $\mathrm{P}_{2} \mathrm{O}_{5}$ ). Dimana $\mathrm{X}=1856.3 \mathrm{~kg} \cdot \mathrm{ha}^{-1} \mathrm{P}_{2} \mathrm{O}_{5}$ atau $5156 \mathrm{~kg} \cdot \mathrm{ha}^{-1} \mathrm{SP}-36$, yaitu $\mathrm{P}$ yang dibutuhkan untuk mencapai kadar $\mathrm{P}$ sangat tinggi pada tanah Andosol Pasir Sarongge. Dosis N dan K yang digunakan adalah $200 \mathrm{~kg} \cdot \mathrm{ha}^{-1}$ urea dan $100 \mathrm{~kg} \cdot \mathrm{ha}^{-1} \mathrm{KCl}$ mengacu pada penelitian Amisnaipa et al. (2009). Diperoleh 100 satuan percobaan dari kombinasi kedua faktor tersebut.

Lahan penelitian yang digunakan diberakan selama satu tahun, selama proses bera juga dilakukan inkubasi. Inkubasi dilakukan untuk uji kalibrasi yaitu penetapan status hara $\mathrm{P}$ tanah (sebagai bedeng utama) dengan inkubasi pupuk $\mathrm{P}$ untuk membuat kategori tingkat kesuburan tanah yang berbeda dari sangat rendah samapai sangat tinggi. Inkubasi dilakukan enam bulan sebelum tanaman. Analisis tanah dilakukan untuk mengetahui tingkat kesuburan tanah, sifat fisik dan sifat kimia tanah.

Lahan percobaan diolah dua minggu sebelum tanam dengan cara dicangkul dan dihaluskan hingga rata. Bedeng-bedeng percobaan dibuat dengan ukuran $1.2 \mathrm{~m} \times 2.5 \mathrm{~m}$ sebanyak 100 bedeng sesuai dengan jumlah satuan percobaan, jarak antar bedeng percobaan adalah $0.5 \mathrm{~m}$. Benih caisin disemaikan di media tanam berupa bahan organik yang diletakkan di tray.

Pemindahan bibit tanaman caisin ke lapangan dilakukan setelah tanaman berumur 14 hari atau setelah muncul 3 daun. Pemeliharaan yang dilakukan di persemaian adalah dengan melakukan penyiraman setiap hari. Bibit caisin dipindahkan di lahan yang telah siap dan ditanam dengan jarak tanam $20 \mathrm{~cm} \times 20 \mathrm{~cm}$ sehingga jumlah populasi tanaman per bedeng adalah 55 tanaman. Jumlah seluruh tanaman adalah 5,500 tanaman. Aplikasi pupuk urea dan $\mathrm{KCl}$ sebanyak $60 \%$ saat tanam dan sisanya sebanyak $40 \%$ diberikan 2 minggu setelah pindah tanam (MST), sedangkan aplikasi pemupukan SP-36 sebanyak 100\% dilakukan satu minggu sebelum tanam.

Tahapan pemeliharaan awal yang dilakukan selama masa tumbuh tanaman caisin meliputi penyulaman tanaman yang mati. Pemeliharaan selanjutnya yang dilakukan adalah penyiraman, pemberantasan gulma dan pengendalian hama dan penyakit. Penyiraman dilakukan setiap hari secara manual sesuai kondisi dan kebutuhan. Penyiangan gulma dilakukan jika terdapat gulma di bedengan. Pengendalian hama dan penyakit dilakukan secara kimia dan manual sesuai dengan kebutuhan. Pemanenan dilakukan ketika tanaman sudah dalam kondisi siap panen panen atau sebelum berbunga yaitu berkisar antara 3-4 minggu setelah pindah tanam. Pemanenan dilakukan dengan cara mencabut tanaman caisin dengan akarnya.

Pengamatan pertumbuhan tanaman dilakukan setiap satu minggu pada 5 tanaman contoh yang dipilih secara acak, sehingga jumlah seluruh tanaman contoh adalah 500 tanaman. Pengamatan dilakukan terhadap peubah pertumbuhan dan peubah panen. Pada peubah pertumbuhan yang diamati adalah peubah tinggi tanaman $(\mathrm{cm})$ dan jumlah daun. Pengamatan peubah panen dilakukan saat pemanenan tanaman caisin. Pengamatan peubah panen yang dilakukan terhadap lima tanaman contoh yang dipilih secara acak antara lain bobot tanaman ${ }^{-1}(\mathrm{~g})$, panjang akar $(\mathrm{cm})$, dan bobot akar $(\mathrm{g})$. Pengamatan yang dilakukan terhadap tanaman per bedeng antara lain bobot total tanaman per bedeng $(\mathrm{g})$, bobot tanaman yang layak pasar per bedeng (g), dan bobot tanaman tidak layak pasar per bedeng (g). Data yang diperoleh dari parameter yang diamati dianalisis statistik uji $\mathrm{F}$ pada taraf $5 \%$, apabila berpengaruh nyata maka dilakukan uji lanjut polynomial orthogonal.

Kebutuhan pemupukan $\mathrm{P}$ pada setiap kelas hara $\mathrm{P}$ tanah untuk caisin didasarkan pada kurva respon hasil relatif yang diperoleh dengan menggunakan analisis regresi. Selanjutnya persamaan regresi tersebut dibuat kurva untuk setiap kelas ketersediaan hara $\mathrm{P}$ tanah. Dosis yang direkomendasikan adalah dosis pupuk $\mathrm{P}$ untuk mencapai hasil maksimum.

\section{HASIL DAN PEMBAHASAN}

\section{Kondisi Umum}

Berdasarkan data cuaca dapat diketahui rata-rata kelembaban udara di Pasir Sarongge 
selama dilakukan penelitian adalah $85.4 \%$ pada bulan April dan 83.9\% pada bulan Mei. Rata-rata suhu maksimum dan minimum pada bulan April adalah $26.8{ }^{\circ} \mathrm{C}$ dan $19{ }^{\circ} \mathrm{C}$ sedangkan pada bulan Mei adalah $27.2^{\circ} \mathrm{C}$ dan $18.5^{\circ} \mathrm{C}$. Rata-rata hari hujan pada bulan April adalah 29 hari dan pada bulan Mei adalah 21 hari (BMKG, 2014).

Persentase tumbuh tanaman caisin di lapangan adalah $89.36 \%$ dan persentase tanaman yang tidak tumbuh adalah $10.64 \%$. Persentase jumlah tanaman caisin yang terserang penyakit akar gada adalah $11.90 \%$. Sifat kimia dan fisik tanah di lokasi penelitian disajikan pada Tabel 1. Tanah Andosol di Pasir Sarongge bertekstur berlempung halus dan memiliki $\mathrm{pH}$ masam. Kapasitas tukar kation (KTK) sedang dan kejenuhan basa (KB) tinggi. Berdasarkan hasil $\mathrm{P}$ terekstrak Bray tingkat kesuburan tanah adalah sedang.

\section{Pengaruh Pembuatan Status Hara P Tanah dan Aplikasi Pemupukan P}

Berdasakran kandungan $\mathrm{P}$ tanah menggunakan pengekstrak Bray, lokasi percobaan tergolong pada kategori $\mathrm{P}$ sedang (Tabel 1). Kondisi ini kurang ideal untuk membangun dosis rekomendasi $\mathrm{P}$ untuk tanaman caisin. Namun demikian di seluruh lokasi penelitian walaupun telah diberakan selama satu tahun ternyata tidak ditemukan kandungan $\mathrm{P}$ yang sangat rendah atau rendah.

\section{Tinggi Tanaman}

Data tinggi tanaman pada Tabel 2 menunjukkan bahwa perlakuan pembuatan status hara $\mathrm{P}$ tanah berpengaruh nyata pada 2 MST dan sangat nyata pada 3 MST. Perlakuan dosis pemupukan $\mathrm{P}$ tidak berpengaruh nyata terhadap tinggi tanaman. Data yang diperoleh tidak menunjukkan adanya interaksi antara pembuatan status hara $\mathrm{P}$ tanah dengan dosis pemupukan $\mathrm{P}$.

\section{Jumlah Daun}

Data jumlah daun tanaman caisin pada Tabel 3 menunjukkan bahwa perlakuan pembuatan status hara $\mathrm{P}$ tanah berpengaruh sangat nyata terhadap jumlah daun pada 3 MST. Perlakuan dosis pemupukan $\mathrm{P}$ tidak berpengaruh nyata terhadap jumlah daun tanaman caisin. Data yang diperoleh tidak menunjukkan adanya interaksi antara pembuatan status hara $\mathrm{P}$ tanah dengan dosis pemupukan $\mathrm{P}$.

Tabel 1. Hasil analisis kimia dan fisika tanah percobaan uji $\mathrm{P}$ tanah (SEAMEO BIOTROP, 2015)

\begin{tabular}{|c|c|c|}
\hline Karakteristik & Metode & $\begin{array}{l}\text { Indeks } \\
\text { Ukuran }\end{array}$ \\
\hline $\mathrm{pH} \mathrm{H} \mathrm{H}_{2} \mathrm{O}$ & $\mathrm{pH}$ meter & $\begin{array}{c}5.1 \\
\text { (masam) }\end{array}$ \\
\hline $\mathrm{pH} \mathrm{KCl}$ & $\mathrm{pH}$ meter & $\begin{array}{c}4.8 \\
\text { (masam) }\end{array}$ \\
\hline C-org (\%) & Walkley\&Black & $\begin{array}{c}4.5 \\
\text { (tinggi) }\end{array}$ \\
\hline N-org (\%) & Kjeldahl & $\begin{array}{c}0.4 \\
\text { (sedang) }\end{array}$ \\
\hline $\mathrm{C} / \mathrm{N}$ & & $\begin{array}{c}13.0 \\
\text { (sedang) }\end{array}$ \\
\hline P Bray I (ppm) & Bray I & $\begin{array}{c}17.3 \\
\text { (sedang) }\end{array}$ \\
\hline $\mathrm{Ca}\left(\mathrm{cmol} \mathrm{kg}^{-1}\right)$ & $\begin{array}{c}\mathrm{NH}_{4} \text {-Acetat } 1 \mathrm{~N} \\
\mathrm{pH} 7\end{array}$ & $\begin{array}{c}13.5 \\
\text { (tinggi) }\end{array}$ \\
\hline $\mathrm{Mg}\left(\mathrm{cmol} \mathrm{kg}^{-1}\right)$ & $\begin{array}{c}\mathrm{NH}_{4} \text {-Acetat } 1 \mathrm{~N} \\
\mathrm{pH} 7\end{array}$ & $\begin{array}{c}1.3 \\
\text { (sedang) }\end{array}$ \\
\hline $\mathrm{K}\left(\mathrm{cmol} \mathrm{kg}^{-1}\right)$ & $\begin{array}{c}\mathrm{NH}_{4} \text {-Acetat } 1 \mathrm{~N} \\
\mathrm{pH} 7\end{array}$ & $\begin{array}{c}0.1 \\
\text { (sangat } \\
\text { rendah) }\end{array}$ \\
\hline $\mathrm{Na}\left(\mathrm{cmol} \mathrm{kg}^{-1}\right)$ & $\begin{array}{c}\mathrm{NH}_{4} \text {-Acetat } 1 \mathrm{~N} \\
\mathrm{pH} 7\end{array}$ & $\begin{array}{c}0.3 \\
\text { (rendah) }\end{array}$ \\
\hline KTK $\left(\mathrm{cmol} \mathrm{kg}^{-1}\right)$ & $\begin{array}{c}\mathrm{NH}_{4} \text {-Acetat } 1 \mathrm{~N} \\
\mathrm{pH} 7\end{array}$ & $\begin{array}{c}24.5 \\
\text { (sedang) }\end{array}$ \\
\hline KB (\%) & $\begin{array}{c}\mathrm{NH}_{4} \text {-Acetat } 1 \mathrm{~N} \\
\mathrm{pH} 7\end{array}$ & $\begin{array}{c}62.0 \\
\text { (tinggi) }\end{array}$ \\
\hline $\mathrm{Al}\left(\mathrm{cmol} \mathrm{kg}^{-1}\right)$ & $\mathrm{KCl} 1 \mathrm{~N}$ & $\begin{array}{c}0.1 \\
\text { (sangat } \\
\text { rendah) }\end{array}$ \\
\hline $\mathrm{H}\left(\mathrm{cmol} \mathrm{kg}^{-1}\right)$ & $\mathrm{KCl} 1 \mathrm{~N}$ & 0.1 \\
\hline \multicolumn{3}{|l|}{ Tekstur : } \\
\hline Pasir (\%) & pipet & 37.0 \\
\hline Debu $(\%)$ & pipet & 34.0 \\
\hline Liat $(\%)$ & pipet & 29.0 \\
\hline
\end{tabular}


Tabel 2. Rata-rata inggi tanaman pada pembuatan status hara $\mathrm{P}$ tanah dan dosis pemupukan $\mathrm{P}$

\begin{tabular}{|c|c|c|c|}
\hline \multirow{3}{*}{ Perlakuan } & \multicolumn{3}{|c|}{ Umur Tanaman (MST) } \\
\hline & 1 & 2 & 3 \\
\hline & \multicolumn{3}{|c|}{ Tinggi Tanaman $(\mathrm{cm})$} \\
\hline \multicolumn{4}{|c|}{ Pembuatan status hara P tanah (kg SP-36 per $\left.7.5 \mathrm{~m}^{2}\right)$} \\
\hline $0(0 \mathrm{X})$ & 8.64 & 14.00 & 26.62 \\
\hline $0.49(1 / 4 \mathrm{X})$ & 9.06 & 15.67 & 25.82 \\
\hline $0.98(1 / 2 \mathrm{X})$ & 8.66 & 15.17 & 26.36 \\
\hline $1.47(3 / 4 \mathrm{X})$ & 8.62 & 15.70 & 26.38 \\
\hline $1.96(\mathrm{X})$ & 8.31 & 14.99 & 25.48 \\
\hline $\mathrm{Uji}^{\mathrm{a}}$ & $\operatorname{tn}$ & $*$ & $\mathrm{~L}^{* *}$ \\
\hline \multicolumn{4}{|c|}{ Dosis pemupukan $\mathrm{P}\left(\mathrm{kg} \mathrm{SP}-36\right.$ per $\left.7.5 \mathrm{~m}^{2}\right)$} \\
\hline $0(0 \mathrm{X})$ & 8.71 & 15.27 & 25.50 \\
\hline $0.49(1 / 4 \mathrm{X})$ & 8.68 & 15.19 & 25.49 \\
\hline $0.98(1 / 2 \mathrm{X})$ & 8.90 & 15.44 & 26.13 \\
\hline $1.47(3 / 4 \mathrm{X})$ & 8.39 & 14.78 & 24.89 \\
\hline $1.96(\mathrm{X})$ & 8.63 & 14.86 & 24.65 \\
\hline $\mathrm{Uji} \mathrm{F}^{\mathrm{b}}$ & tn & tn & tn \\
\hline Interaksi & tn & tn & tn \\
\hline $\mathrm{KK}$ & 8.91 & 11.16 & 11.42 \\
\hline \multicolumn{4}{|c|}{$\begin{aligned} \text { Keterangan: }{ }^{a} \text { Uji } \mathrm{F} \text { untuk melihat pengaruh pembuatan } \\
\text { status hara } \mathrm{P} \text { tanah; }{ }^{\mathrm{b}} \mathrm{Uji} \mathrm{F} \text { untuk melihat } \\
\text { pengaruh aplikasi pemupukan } \mathrm{P} ; *=\text { Nyata } \\
\text { pada } \mathrm{P}<0.05 ; * *=\text { sangat nyata pada } \mathrm{P}< \\
\\
0.01 ; \text { tn }=\text { tidak nyata; MST }=\text { minggu setelah } \\
\text { pindah tanam; } \mathrm{L}=\text { linier pada uji lanjut } \\
\text { polinomial }\end{aligned}$} \\
\hline
\end{tabular}

Tabel 3. Rata-rata jumlah daun pada pembuatan status hara $\mathrm{P}$ tanah dan dosis pemupukan $\mathrm{P}$

\begin{tabular}{|c|c|c|c|}
\hline \multirow{3}{*}{ Perlakuan } & \multicolumn{3}{|c|}{ Umur Tanaman (MST) } \\
\hline & 1 & 2 & 3 \\
\hline & \multicolumn{3}{|c|}{ Jumlah Daun (Helai) } \\
\hline \multicolumn{4}{|c|}{ Pembuatan status hara P tanah (kg SP-36 per $\left.7.5 \mathrm{~m}^{2}\right)$} \\
\hline $0(0 \mathrm{X})$ & 4.61 & 6.31 & 7.68 \\
\hline $0.49(1 / 4 \mathrm{X})$ & 4.56 & 6.75 & 9.07 \\
\hline $0.98(1 / 2 \mathrm{X})$ & 4.65 & 6.49 & 8.62 \\
\hline $1.47(3 / 4 \mathrm{X})$ & 4.54 & 6.66 & 8.59 \\
\hline $1.96(\mathrm{X})$ & 4.52 & 6.43 & 8.37 \\
\hline $\mathrm{Uji}^{\mathrm{a}}$ & tn & tn & $* *$ \\
\hline \multicolumn{4}{|c|}{ Dosis pemupukan $\mathrm{P}\left(\mathrm{kg} \mathrm{SP}-36\right.$ per $\left.7.5 \mathrm{~m}^{2}\right)$} \\
\hline $0(0 \mathrm{X})^{1}$ & 4.50 & 6.48 & 8.51 \\
\hline $0.49(1 / 4 \mathrm{X})$ & 4.66 & 6.63 & 8.71 \\
\hline $0.98(1 / 2 \mathrm{X})$ & 4.65 & 6.66 & 8.65 \\
\hline $1.47(3 / 4 \mathrm{X})$ & 4.55 & 6.46 & 8.20 \\
\hline $1.96(\mathrm{X})$ & 4.52 & 6.41 & 8.26 \\
\hline $\mathrm{Uji}^{\mathrm{b}}$ & tn & tn & tn \\
\hline Interaksi & tn & tn & tn \\
\hline KK & 7.29 & 7.72 & 11.82 \\
\hline \multicolumn{4}{|c|}{$\begin{aligned} \text { Keterangan: } & { }^{\mathrm{a}} \mathrm{Uji} \mathrm{F} \text { untuk melihat pengaruh pembuatan } \\
& \text { status hara } \mathrm{P} \text { tanah; }{ }^{\mathrm{b}} \mathrm{Uji} \mathrm{F} \text { untuk melihat } \\
& \text { pengaruh aplikasi pemupukan } \mathrm{P} ; * *=\text { sangat } \\
& \text { nyata pada } \mathrm{P}<0.01 ; \text { tn }=\text { tidak nyata; MST }= \\
& \text { minggu setelah pindah tanam; } \mathrm{L}=\text { linier pada } \\
& \text { uji lanjut polynomial }\end{aligned}$} \\
\hline
\end{tabular}

Panjang Akar, Bobot Akar dan Bobot Tanaman $^{-1}$

Data panjang akar, bobot akar, dan bobot tanaman caisin pada Tabel 4 menunjukkan bahwa perlakuan pembuatan status hara $\mathrm{P}$ tanah berpengaruh nyata terhadap bobot akar dan berpengaruh sangat nyata terhadap bobot tanaman. Perlakuan dosis pemupukan $\mathrm{P}$ tidak berpengaruh nyata terhadap panjang akar, bobot akar, dan bobot tanaman caisin. Data yang diperoleh tidak menunjukkan adanya interaksi antara pembuatan status hara $\mathrm{P}$ tanah dengan dosis pemupukan $\mathrm{P}$.

\section{Bobot Tidak Layak Pasar dan Bobot Layak Pasar}

Data bobot tidak layak pasar dan bobot layak pasar tanaman caisin pada Tabel 5 menunjukkan bahwa perlakuan pembuatan status hara $\mathrm{P}$ tanah berpengaruh sangat nyata terhadap bobot tidak layak pasar per bedeng, bobot layak pasar per bedeng, bobot layak pasar ha ${ }^{-1}$, dan bobot tidak layak pasar $\mathrm{ha}^{-1}$. Perlakuan dosis pemupukan $\mathrm{P}$ tidak berpengaruh terhadap bobot tidak layak pasar dan bobot layak pasar. Data yang diperoleh tidak menunjukkan adanya interaksi antara pembuatan status hara $\mathrm{P}$ tanah dengan dosis pemupukan $\mathrm{P}$.

\section{Bobot Total}

Data bobot total tanaman pada Tabel 6 menunjukkan bahwa pembuatan status hara $\mathrm{P}$ tanah berpengaruh sangat nyata terhadap bobot total per bedeng dan bobot total hektar. Perlakuan dosis pemupukan $\mathrm{P}$ tidak berpengaruh nyata terhadap bobot total per bedeng dan bobot total hektar. Data yang diperoleh tidak menunjukkan adanya interaksi antara pembuatan status hara $\mathrm{P}$ tanah dengan dosis pemupukan $\mathrm{P}$.

Perlakuan pembuatan status hara $\mathrm{P}$ tanah mampu meningkatkan pertumbuhan dan hasil tanaman yaitu tinggi tanaman, jumlah daun, bobot akar, bobot tanaman, bobot layak pasar per bedeng, bobot layak pasar hektar, bobot total per bedeng, dan bobot total hektar secara Linier (Tabel 5 dan Tabel 6). Berdasarkan data yang diperoleh, perlakuan pembuatan status hara $\mathrm{P}$ tanah pada lokasi percobaan dapat digunakan untuk melakukan 
uji korelasi dalam penetapan extraktan yang sesuai untuk caisin.

Perlakuan pembuatan status hara $\mathrm{P}$ tanah berpengaruh sangat nyata terhadap pertumbuhan tinggi tanaman pada 3 MST, jumlah daun pada 3 MST, bobot tanaman, bobot tidak layak pasar per bedeng, tidak layak pasar ha ${ }^{-1}$, bobot layak pasar per bedeng, bobot total per bedeng, dan bobot total ha $\mathrm{a}^{-1}$. Pola respon bobot tanaman layak pasar terhadap pembuatan status hara $\mathrm{P}$ tanah adalah linier, artinya semakin tinggi kandungan $\mathrm{P}$ yang tersedia bagi tanaman semakin tinggi hasil tanaman layak pasar yang diperoleh. Ketersediaan P yang lebih baik menyebabkan hasil yang lebih tinggi dan kualitas tanaman lebih baik, sehingga memungkinkan tanaman untuk mencapai potensi genetiknya (Sanders $e t$ al., 2012). Berdasarkan hasil yang diperoleh dapat diketahui bahwa pembuatan status hara $\mathrm{P}$ tanah berhasil meningkatkan kandungan hara $\mathrm{P}$ tanah yang tersedia di tanah Andosol Kebun Percobaan Pasir Sarongge. Adanya pertumbuhan dan perkembangan keseluruhan tanaman dibandingkan perlakuan kontrol menunjukkan keberhasilan dalam pembuatan tingkatan kandungan hara fosfor tanah (Izhar et al., 2012).
Tabel 4. Panjang akar, bobot akar, dan bobot tanaman caisin pada pembuatan status hara $\mathrm{P}$ tanah dan dosis pemupukan $\mathrm{P}$

\begin{tabular}{|c|c|c|c|}
\hline Perlakuan & $\begin{array}{c}\text { Panjang } \\
\text { Akar } \\
(\mathrm{cm})\end{array}$ & $\begin{array}{c}\text { Bobot } \\
\text { Akar } \\
(\mathrm{g})\end{array}$ & $\begin{array}{c}\text { Bobot } \\
\text { Tanaman } \\
(\mathrm{g})\end{array}$ \\
\hline \multicolumn{4}{|c|}{ Pembuatan status hara P tanah (kg SP-36 per $7.5 \mathrm{~m}^{2}$ ) } \\
\hline $0(0 \mathrm{X})$ & 14.24 & 2.62 & 34.21 \\
\hline $0.49(1 / 4 \mathrm{X})$ & 14.81 & 3.22 & 50.38 \\
\hline $0.98(1 / 2 \mathrm{X})$ & 14.89 & 2.87 & 47.63 \\
\hline $1.47(3 / 4 \mathrm{X})$ & 14.44 & 2.69 & 46.43 \\
\hline $1.96(\mathrm{X})$ & 13.65 & 2.69 & 48.38 \\
\hline $\mathrm{Uji}^{\mathrm{a}}$ & tn & $*$ & $\mathrm{~L} * *$ \\
\hline \multicolumn{4}{|c|}{ Dosis pemupukan $\mathrm{P}\left(\mathrm{kg} \mathrm{SP}-36\right.$ per $\left.7.5 \mathrm{~m}^{2}\right)$} \\
\hline $0(0 \mathrm{X})$ & 14.14 & 2.65 & 41.67 \\
\hline $0.49(1 / 4 \mathrm{X})$ & 14.78 & 2.72 & 41.89 \\
\hline $0.98(1 / 2 X)$ & 14.56 & 3.01 & 50.36 \\
\hline $1.47(3 / 4 \mathrm{X})$ & 14.41 & 2.72 & 44.98 \\
\hline $1.96(X)$ & 14.15 & 2.99 & 48.13 \\
\hline $\mathrm{Uji} \mathrm{F}^{\mathrm{b}}$ & tn & tn & tn \\
\hline Interaksi & tn & tn & tn \\
\hline $\mathrm{KK}$ & 14.00 & 21.55 & 26.93 \\
\hline \multicolumn{4}{|c|}{$\begin{aligned} & \text { Keterangan: }{ }^{\text {a}} \text { Uji } \mathrm{F} \text { untuk melihat pengaruh pembuatan } \\
& \text { status hara } \mathrm{P} \text { tanah; }{ }^{\mathrm{b}} \mathrm{Uji} \mathrm{F} \text { untuk melihat } \\
& \text { pengaruh aplikasi pemupukan } \mathrm{P} ; *= \\
& \text { Nyata pada } \mathrm{P}<0.05 ; * *=\text { sangat nyata } \\
& \text { pada } \mathrm{P}<0.01 ; \text { tn }=\text { tidak nyata; } \mathrm{L}=\text { linier } \\
& \text { pada uji lanjut polynomial }\end{aligned}$} \\
\hline
\end{tabular}

Tabel 5. Bobot tidak layak pasar dan bobot layak pasar tanaman caisin pada pembuatan status hara $\mathrm{P}$ tanah dan dosis pemupukan $\mathrm{P}$

\begin{tabular}{|c|c|c|c|c|}
\hline Perlakuan & $\begin{array}{l}\text { Bobot Tidak } \\
\text { Layak per } \\
\text { Bedeng }(\mathrm{g})\end{array}$ & $\begin{array}{c}\text { Bobot Layak } \\
\text { per Bedeng }(\mathrm{g})\end{array}$ & $\begin{array}{l}\text { Bobot Tidak } \\
\text { Layak ha }^{-1} \\
\text { (ton) }\end{array}$ & $\begin{array}{c}\text { Bobot Layak } \\
\text { ha }^{-1} \text { (ton) }\end{array}$ \\
\hline \multicolumn{5}{|c|}{ Pembuatan status hara $\mathrm{P}$ tanah (kg SP-36 per $\left.7.5 \mathrm{~m}^{2}\right)$} \\
\hline $0(0 \mathrm{X})$ & 2085.35 & 2533.15 & 5.70 & 6.65 \\
\hline $0.49(1 / 4 \mathrm{X})$ & 2818.30 & 3097.95 & 6.90 & 8.30 \\
\hline $0.98(1 / 2 \mathrm{X})$ & 2840.95 & 3115.20 & 7.55 & 8.35 \\
\hline $1.47(3 / 4 \mathrm{X})$ & 2804.60 & 3205.05 & 7.45 & 8.65 \\
\hline $1.96(\mathrm{X})$ & 2586.45 & 3274.00 & 6.80 & 8.70 \\
\hline $\mathrm{Uji} \mathrm{F}^{\mathrm{a}}$ & $\mathrm{L}^{* *}$ & $\mathrm{~L}^{* *}$ & $\mathrm{~L}^{* *}$ & $\mathrm{~L}^{* *}$ \\
\hline \multicolumn{5}{|c|}{ Dosis pemupukan P (kg SP-36 per $\left.7.5 \mathrm{~m}^{2}\right)$} \\
\hline $0(0 \mathrm{X})$ & 2597.20 & 3016.30 & 6.90 & 8.00 \\
\hline $0.49(1 / 4 \mathrm{X})$ & 2681.00 & 3083.40 & 7.10 & 8.25 \\
\hline $0.98(1 / 2 \mathrm{X})$ & 2611.50 & 3267.70 & 6.95 & 8.70 \\
\hline $1.47(3 / 4 \mathrm{X})$ & 2565.20 & 3039.80 & 6.90 & 8.15 \\
\hline $1.96(\mathrm{X})$ & 2480.75 & 2818.15 & 6.55 & 7.55 \\
\hline Uji $F^{b}$ & tn & tn & tn & tn \\
\hline Interaksi & tn & tn & tn & tn \\
\hline KK & 22.00 & 17.05 & 22.75 & 17.57 \\
\hline
\end{tabular}

Keterangan: ${ }^{a} \mathrm{Uji} \mathrm{F}$ untuk melihat pengaruh pembuatan status hara $\mathrm{P}$ tanah; ${ }^{\mathrm{b}} \mathrm{Uji} \mathrm{F}$ untuk melihat pengaruh aplikasi pemupukan $\mathrm{P} ; * *=$ sangat nyata pada $\mathrm{P}<0.01$; tn = tidak nyata; $\mathrm{L}=$ linier pada uji lanjut polynomial. 
Tabel 6. Bobot total tanaman caisin pada pembuatan status hara $\mathrm{P}$ tanah dan dosis pemupukan $\mathrm{P}$

\begin{tabular}{|c|c|c|}
\hline Perlakuan & $\begin{array}{c}\text { Bobot } \\
\text { Total per } \\
\text { Bedeng } \\
\text { (g) }\end{array}$ & $\begin{array}{c}\text { Bobot } \\
\text { Total } \\
\text { ha }^{-1} \\
\text { (ton) }\end{array}$ \\
\hline \multicolumn{3}{|c|}{ Pembuatan status hara P tanah (kg SP-36 per $\left.7.5 \mathrm{~m}^{2}\right)$} \\
\hline $0(0 \mathrm{X})$ & 4618.60 & 12.35 \\
\hline $0.49(1 / 4 \mathrm{X})$ & 5716.05 & 15.30 \\
\hline $0.98(1 / 2 \mathrm{X})$ & 5956.20 & 15.95 \\
\hline $1.47(3 / 4 \mathrm{X})$ & 6009.65 & 16.05 \\
\hline $1.96(\mathrm{X})$ & 5860.35 & 15.70 \\
\hline $\mathrm{Uji}^{\mathrm{a}}$ & $\mathrm{L}^{* *}$ & $\mathrm{~L}^{* *}$ \\
\hline \multicolumn{3}{|c|}{ Dosis pemupukan $\mathrm{P}\left(\mathrm{kg} \mathrm{SP}-36\right.$ per $\left.7.5 \mathrm{~m}^{2}\right)$} \\
\hline $0(0 \mathrm{X})^{1}$ & 5613.55 & 14.90 \\
\hline $0.49(1 / 4 \mathrm{X})$ & 5764.35 & 15.35 \\
\hline $0.98(1 / 2 X)$ & 5879.15 & 15.65 \\
\hline $1.47(3 / 4 \mathrm{X})$ & 5604.90 & 15.05 \\
\hline $1.96(\mathrm{X})$ & 5298.90 & 14.10 \\
\hline $\mathrm{Uji}^{\mathrm{b}}$ & tn & th \\
\hline Interaksi & tn & tn \\
\hline KK & 19.13 & 19.36 \\
\hline \multicolumn{3}{|c|}{$\begin{aligned} \text { Keterngan: }{ }^{\mathrm{a}} \text { Uji } \mathrm{F} \text { untuk melihat pengaruh pembuat } \\
\text { status hara } \mathrm{P} \text { tanah; }{ }^{\mathrm{b}} \mathrm{Uji} \mathrm{F} \text { untuk melih } \\
\text { pengaruh aplikasi pemupukan } \mathrm{P} ; * * \\
\\
\text { sangat nyata pada } \mathrm{P}<0.01 ; \text { tn }=\text { tid } \\
\text { nyata; } \mathrm{L}=\text { linier pada uji lanj } \\
\text { polynomial. }\end{aligned}$} \\
\hline
\end{tabular}

Ketersediaan hara P yang cukup selama masa pertumbuhan dan perkembangan tanaman dapat menyebabkan pemupukan $\mathrm{P}$ tidak berpengaruh terhadap pertumbuhan dan hasil tanaman. Alviana dan Susila (2009) melaporkan bahwa perlakuan dosis pemupukan tidak akan terlihat pengaruhnya terhadap tanaman bilamana kandungan hara yang tersimpan dalam tanah dapat menjamin kebutuhan hara selama pertumbuhan tanaman.

Kandungan bahan organik yang tinggi pada lahan penelitian dapat menjadi salah satu penyebab tidak berpengaruhnya pemupukan $\mathrm{P}$. Kandungan C-organik pada lahan penelitian yang digunakan adalah tinggi sedangkan kandungan $\mathrm{N}$-organik dan $\mathrm{C} / \mathrm{N}$ adalah sedang. Djuniwati et al. (2007) melaporkan bahwa bahan organik dapat meningkatkan $\mathrm{pH}, \mathrm{P}$ tersedia, $\mathrm{P}$ organik, dan $\mathrm{P}$ anorganik. Peningkatan $\mathrm{pH}$ dan $\mathrm{P}$ tersedia di dalam tanah menyebabkan hara yang dibutuhkan tanaman semakin tersedia sehingga pemupukan tidak memberikan pengaruh yang nyata.
Curah hujan yang tinggi selama penelitian dapat mempengaruhi air irigasi dan dapat menurunkan $\mathrm{pH}$ tanah. Persentase $\mathrm{P}$ anorganik, $\mathrm{P}$ organik, dan $\mathrm{P}$ yang tersedia untuk tanaman dalam tanah dapat juga dipengaruhi oleh irigasi, sehingga pengelolaan irigasi yang sesuai dapat meningkatkan ketersediaan hara P yang ada di tanah (Wang dan Zhang, 2010).

Kemasaman tanah dapat mempengaruhi ketersediaan P yang tersedia bagi tanaman dan dapat mempengaruhi kerja akar dalam penyerapan hara, sehingga mempengaruhi pertumbuhan dan hasil tanaman caisin. Pada lahan penelitian yang digunakan $\mathrm{pH}$ yang terukur adalah masam. Melinda (2012) melaporkan bahwa bobot segar daun caisin tanpa perlakuan kapur pertanian memberikan hasil terendah pada $\mathrm{pH}$ tanah masam, sedangkan perlakuan kapur pertanian pada tanah masam meningkatkan bobot segar daun caisin, meningkatkan $\mathrm{pH}$ tanah dan menurunkan Al.

Serangan penyakit pada tanaman dapat mempengaruhi pertumbuhan dan hasil tanaman. Pada penelitian ini penyakit yang menyerang tanaman caisin adalah akar gada yang disebabkan oleh Plasmodiophora brassicae. Persentase jumlah tanaman yang terserang penyakit akar gada adalah $11.90 \%$. Adanya serangan penyakit akar gada pada tanaman caisin menyebabkan kerja akar menjadi terganggu sehingga pertumbuhan tanaman tidak normal dan hasil tanaman rendah. Tanaman caisin yang terserang penyakit akar gada memiliki ciri akar yang membesar (bengkak) berbentuk gada, bentuk daun sempit dan runcing, tinggi tanaman lebih rendah dibandingkan tanaman normal, dan layu pada siang hari. Hadiwiyono et al. (2011) melaporkan bahwa casin rentan terhadap infeksi patogen akar gada dan dapat menjadi perangkap patogen tersebut.

Bobot tanaman layak pasar per hektar pada pembuatan status hara $\mathrm{P}$ tanah berkisar antara 6.65-8.70 ton.ha ${ }^{-1}$, sedangkan bobot tanaman layak pasar per hektar pada beberapa dosis pemupukan $\mathrm{P}$ berkisar antara 7.55-8.70 ton.ha ${ }^{-1}$. Bobot total tanaman per hektar pada pembuatan status hara $\mathrm{P}$ tanah berkisar antara 12.35-16.05 ton.ha ${ }^{-1}$, sedangkan bobot total tanaman per hektar pada beberapa dosis pemupukan $\mathrm{P}$ berkisar antara 14.10-15.65 ton.ha ${ }^{-1}$. 
Bobot tanaman layak pasar per hektar pada pengkondisan hara $\mathrm{P}$ tanah dan dosis pemupukan $\mathrm{P}$ lebih rendah jika dibandingkan dengan produktivitas caisin di Jawa Barat pada tahun 2011. Bobot total per hektar pada pengkondisan hara $\mathrm{P}$ tanah sama jika dibandingkan dengan produktivitas caisin di Jawa Barat tahun 2011, sedangkan bobot total per hektar pada dosis pemupukan $\mathrm{P}$ lebih tinggi jika dibandingkan produktivitas caisin di Jawa Barat pada tahun 2011. Produktivitas caisin di Jawa Barat tahun 2011 adalah 13.18 ton.ha ${ }^{-1}$ (BPS, 2012).

Penelitian ini menunjukkan bahwa Penetapan dosis rekomendasi pemupukan fosfor pada budidaya caisin di tanah Andosol Kebun Percobaan Pasir Sarongge belum dapat dilakukan sebab tanaman tidak menunjukkan respon yang berbeda terhadap pemupukan. Diduga kandungan hara P dalam tanah (sedang) sudah mampu memenuhi kebutuhan tanaman. Amisnaipa (2005) melaporkan bahwa pada kelas ketersediaan hara $\mathrm{K}$ tinggi dan sangat tinggi tidak perlu dilakukan pemupukan karena tanaman tidak memberikan respon terhadap pemupukan. Izhar (2012) melaporkan bahwa tanah dengan kandungan hara $\mathrm{P}$ dan $\mathrm{K}$ kategori sedang sampai tinggi tidak memerlukan adanya pemberian rekomendasi pemupukan. Percobaan ini dilakukan pada lokasi kebun percobaan yang pernah diberikan pemupukan P. Perlakukan bera selama 1 tahun ternyata belum mampu menurunkan jumlah $\mathrm{P}$ tanah pada Andosols Pasir Sarongge.

\section{KESIMPULAN}

Pembuatan status hara $\mathrm{P}$ tanah berpengaruh sangat nyata terhadap pertumbuhan dan hasil tanaman caisin. Pada Andosol Pasir Sarongge dengan kandungan $P$ tanah "sedang", perlakuan pemupukan P tidak memberikan pengaruh yang nyata terhadap pertumbuhan dan hasil tanaman caisin. Serangan penyakit akar gada dapat menjadi salah satu penyebab pemupukan tidak berpengaruh pada tanaman. Persentase jumlah tanaman yang terserang penyakit akar gada adalah $11.90 \%$. Dosis rekomendasi pemupukan P di Kebun Percobaan Pasir Sarongge belum dapat ditentukan.

\section{SARAN}

Perlu dilakukan penelitian pada lahan dengan status awal hara $\mathrm{P}$ tersedia yang rendah sehingga rekomendasi pemupukan dapat ditetapkan.

\section{DAFTAR PUSTAKA}

Alviana, V.F., A.D. Susila. 2009. Optimasi dosis pemupukan pada budidaya cabai (Capsicum annuиm L.) menggunakan irigasi tetes dan mulsa polyethylen. J Agron Indonesia. 37(1): 28-33.

Amisnaipa. 2005. Rekomendasi pemupukan kalium pada budidaya tomat menggunakan irigasi tetes dan mulsa polyethylene. Tesis. Sekolah Pasca sarjana. Institut Pertanian Bogor. Bogor.

Amisnaipa, A.D. Susila, R. Situmorang, D.W. Purnomo. 2009. Penentuan kebutuhan pupuk kalium untuk budidaya tomat menggunakan irigasi tetes dan mulsa polyethylen. J. Agron Indonesia. 37(2): 115-122.

Badan Meteorologi dan Geofisika. 2014. Data Iklim. Stasiun Klimatologi Dramaga. Bogor.

[BPS] Badan Pusat Satistik. 2012. Luas panen dan produksi tanaman sayuran Provinsi Jawa Barat tahun 2010-2011. http:// bps.go.id. [09 Maret 2013].

[BPS] Badan Pusat Statistik. 2013. Rata-rata konsumsi kalori (kkal) per kapita sehari menurut kelompok makanan. http://bps. go.id. [09 Maret 2013].

Djuniwati, S., H.B. Pulunggono, Suwarno. 2007. Pengaruh pemberian bahan organik (Centrosema pubescens) dan fosfat alam terhadap aktivitas fosfatase dan fraksi P tanah latosol di Darmaga, Bogor. J. Tanah dan Lingkungan. 9(1): 10-15.

Food Agriculture Organization of the United Nations. 2006. More Fruit and Vegetables. http://fao.org. [09 Maret 2013]. 
Fei, L., M. Zhao, X. Chen, Y. Shi. 2011. Effects of phosphorus accumulation in soil with the utilization ages of the vegetable greenhouses in the suburb of Shenyang. Procedia Environmental Sciences. 8:16-20. DOI: $10.1016 / \mathrm{j}$. proenv.2011.10.005.

Hadiwiyono, Sholahuddin, E. Sulastri. 2011. Efektivitas caisin sebagai tanaman perangkap patogen untuk pengendalian penyakit akar gada pada kubis. J. HPT Tropika. 11(1): 22-27.

Hendriyani, N.M.Y., I.K. Suada, N.W. Suniti. 2012. Pengendalian penyakit akar gada yang disebabkan oleh Plasmodiophora brassicae Wor. pada tanaman kubis (Brassica oleraceae L. var. capitata L.) dengan beberapa ekstrak tanaman. AGROTROP. 2(2): 197-203.

Izhar, L. 2012. Pengembangan uji tanah untuk membangun kriteria rekomendasi pemupukan fosfor dan kalium pada tanaman tomat. Disertasi. Sekolah Pasca sarjana. Institut Pertanian Bogor.

Izhar, L., A.D. Susila. 2010. Rekomendasi pemupukan fosfor dan potasium berdasarkan analisis hara tanah pada tanaman sayuran. J. Hort. Indonesia. 1(2): 81-87.

Izhar, L., A.D. Susila, B.S. Purwoko, A. Sutandi, I.W. Mangku. 2012. Penentuan metode terbaik uji fosfor untuk tanaman tomat pada tanah inceptisols. J. Hort. 22(2): 139-147.

Kementerian Pertanian. 2012. Data produksi sayuran Indonesia. http://deptan.go.id. [09 Maret 2013].
Melinda, A. 2012. Pengaruh pupuk neutralizer, kaptan, dan urea terhadap caisin varietas Tosakan pada podsolik Jasinga. Skripsi. Program Sarjana. Institut Pertanian Bogor. Bogor.

Motlagh, S.M., A. Pirzad, B. Delkhosh. 2012. Effect of biological phosphorus and irrigation disruption on biomass seed yield and protein content of canola (Brassica napus L.). Intl Res J. Appl Basic Sci. 3(5): 961-967. ISSN: 2251-838X.

Sanders, J.L., S. Murphy, A. Noble, R.J. Melgar, J. Perkins. 2012. Improving phosphorus use efficiency with polymer technology. Procedia Engineering. 46: 178-184. DOI: 10.1016/j.proeng.2012. 09.463.

Savci, S. 2012. Investigation of effect of chemical fertilizers on environment. APCBEE Procedia. 1: 287-292. DOI : 10.1016/j.apcbee.2012.03.047.

Tan, K.H. 1998. Principles of Soil Chemistry. 3rd edition. Marcel Dekker. New York (NY).

Toth, G., R.A. Guicharnaud, B. Toth, T. Hermann. 2014. Phosphorus levels in corplands of te European Union with implications for P fertilizer use. Europe J. Agronomy. 55: 42-52.

Wang, A.H., S.X. Li, S. Malhi. 2008. Effects of fertilization and other agronomic measures on nutritional quality of crops. J. Sci Food Agric. 88: 7-23.

Wang, Y., Y. Zhang. 2010. Soil-phosphorus distribution and availability as affected by subsurface irrigation. J. Plant Nutr Soil Sci. 173: 345-352. DOI: 10.1002/ jpln.200800284. 